phần mềm $25,51 \%$, veo vách ngăn mũi $14,29 \%$, kết hợp sẹo và tổn thương mũi xoang 4,08\%, di chứng tổn thương mũi, xoang với các tổn thương khác $21,43 \%$.

- Có 85,71\% không có di chứng liên quan đến chức năng mũi, xoang chiếm tỷ lệ cao nhất, di chứng ảnh hưởng đến hạn chế mức độ thở là $3,06 \%$ và viêm mũi xoang $6,12 \%$, di chứng khác là $5,10 \%$.

- Chỉ định chụp CTscanner chiếm tỷ lệ cao nhất $88,78 \%$, EEG chiếm $31,63 \%$, Xquang và MRI đều chiếm $15,31 \%$, siêu âm, nội soi $2,04 \%$. Chỉ định khám chuyên khoa Tai mũi họng chiếm tỷ lệ cao nhất là $18,37 \%$, chuyên khoa Mắt $10,20 \%$, chuyên khoa thần kinh $7,14 \%$ và chuyên khoa Răng hàm mặt $6,12 \%$.

- Kết quả phát hiên tổn thương trùng hợp với chẩn đoán của bệnh viện là $84,69 \%$, kết quả không trùng hợp với chẩn đoán của bệnh viện là $15,31 \%$.

- Vật gây thương tích do vật tày chiếm tỷ lệ cao nhất là 45,92\%, vật sắc, nhơn chiếm $13,27 \%$, hỏa khí $1,02 \%$, không rõ vật gây thương tích là $3,06 \%$. Có 36,73\% các trường hợp không yêu cầu giám định vật gây thương tích.

\section{TÀI LIÊU THAM KHẢO}

1. Đă̆ng Thanh (2012). Nghiên cứu đặc điểm dịch tể và lâm sàng chấn thương tai mũi hơng tai bếnh viện Trung ương Huế. Tạp chí Y dược học Quân sự, 153-160, số 2-2012.

2. Thông tư' số $\mathbf{2 0 / 2 0 1 4 / T T - ~ B Y T ~ n g a ̀ y ~} 12 / 6 / 2014$ của Bộ Y tế.

3. Thông tư số $22 / 2019 / T T-$ BYT ngày $28 / 8 / 2019$ của Bộ Y tế.

4. Nguyễn Hữu Khôi (2005). Nghiên cứu một số yếu tố dịch tễ của gãy xương chính mũi do chấn thương. Tạp chí Y học Thành phố Hồ Chí Minh. Tập 9, (1), 2005.

\title{
THỰC TRẠNG BÊ̂NH VIÊM LỢI VÀ VÊ SINH RĂNG MIỆNG CỦA HỌC SINH LỚP 6 TRƯỜNG THCS CỔ BI, GIA LÂM, HÀ Nô̂I NĂM 2020
}

Trần Thị Mỹ Hạnh ${ }^{1}$, Hoàng Hồng Xiêm ${ }^{1}$, Vũ Mạnh Tuấn ${ }^{1}$, Nguyễn Phú Thắng ${ }^{1}$, Đàm Văn Việt ${ }^{2}$, Phạm Thị Tuyết Nga ${ }^{1}$

\section{TÓM TẮT}

Mục tiêu: nhận xét thực trạng bệnh viêm lợi và vệ sinh rẳng miệng của học sinh lớp 6 trường THCS Cổ Bi, Gia Lâm, Hà Nội. Đối tượng: Học sinh lớp 6 trường THCS Cổ Bi, Gia Lâm, Hà Nội. Phương pháp nghiến cứu: mô tả cắt ngang. Kết quả: tî lể hoc sinh bị viêm lợi là 78,29\%. Tỉ lể học sinh viêm lợi nhe chiếm $31,01 \%$, viêm trung bình chiếm $29,46 \%$ và̀ viêm nặng chiếm $17,83 \%$. Tỉ lệ học sinh có xếp loại OHI-S rất tốt chiếm $0 \%$, tốt chiếm $41,09 \%$, trung bình chiếm $56,59 \%$ và kém chiếm $2,32 \%$. Kết luận: tỉ lệ học sinh bị viêm lợi còn cao, tình trạng vệ sinh răng miệng của học sinh ở mức trung bình. lớp 6.

Tư khóa: viêm lợi, vệ sinh răng miêng, học sinh

\section{SUMMARY}

THE SEVERITY OF GINGIVITIS AND ORAL HYGIENE PRACTICE AMONG 6 $^{\text {TH }}$ GRADERS

FROM CO BI SECONDARY SCHOOL, GIA LAM, HA NOI 2020

Objective: assess the severity of gingivitis and oral hygiene practice among $6^{\text {th }}$ graders from $\mathrm{Co} \mathrm{Bi}$,

\footnotetext{
1 Trường Đại học Y Hà Nọi

²Bênh viên Răng Hàm Măt Trung Uơng Hà Nôii

Chịu trách nhiệm chính: Trần Thị Mỹ Hạnh

Email: tranmyhanh@hmu.edu.vn

Ngày nhân bài: 22.6.2021

Ngày phản biên khoa hoc: 19.8.2021

Ngày duyệt bài: 26.8.2021
}

Gia Lam, Ha Noi. Subjects: $6^{\text {th }}$ graders from Co Bi, Gia Lam, Ha Noi. Method: cross sectional study. Results: the number of student with gingivitis accounts for $78,29 \%$. The number of students with mild, moderate and severe gingivitis is $31,01 \%$, $29,46 \%$ and $17,83 \%$, respectively. When it comes to simplified oral hygiene index (OHI-S), student with excellent, good, fair and poor score account for $0 \%$, $41,09 \%, 56,59 \%$ and $2,32 \%$. Conclusion: the presence of gingivitis among students is at high incidence and oral hygiene is still and at fair level.

Keyword: gingivitis, oral hygiene, $6^{\text {th }}$ graders.

\section{I. Đă̆T VẤN ĐỀ}

Sâu răng, viêm lợi là những bệnh lý răng miệng phổ biến ở trẻ em. Tại Việt Nam, tỉ lệ học sinh mắc bệnh răng miệng khoảng $85 \%{ }^{1}$. Các bệnh răng miệng này không những ảnh hưởng tới chức năng ăn nhai, thẩm mỹ mà còn gây những biến chứng tại chỗ và toàn thân. Việc hiểu biết và thực hành chăm sóc răng miệng đúng cách, hiệu quả đóng vai trò quyết định trong dự phòng các bênh răng miệng. Ngày nay, vấn đề chăm sóc răng miệng ở trẻ em đã được quan tâm nhiều, chương trình nha học đường đã được triển khai rộng khắp 58/63 tỉnh thành và đạt được những thành tựu đáng kểe tuy nhiên tỷ lệ trẻ em bị mắc các bệnh lý răng miệng vẫn còn cao. Theo kết quả điều tra sức khỏe răng miệng toàn quốc năm 2001, tỉ lệ viêm lợi ở trẻ em 12 
tuổi là 92,6\%3․ Học sinh lớp 6 là lứa tuổi bắt đâu của bộ răng vĩnh viễn, ở lứa tuổi 11-12 này trẻ cần được trang bị kiến thức chăm sóc sức khỏe răng miệng, đây cũng là thời điểm quan trọng nhất để tìm hiểu và đưa ra các biện pháp dự phòng bệnh răng miệng. Vì vậy, chúng tôi tiên hành nghiên cứu này với mục đích: Nhận xét tình trạng bệnh viêm lợi và vệ sinh răng miệng của học sinh lớp 6 trường THCS Cổ Bi, Gia Lâm, Hà Nội năm 2020.

\section{II. ĐỐI TƯỚNG VÀ PHƯƠ'NG PHÁP NGHIÊN CỨU}

Đối tượng nghiên cứu: học sinh lớp 6 trường THCS Cổ Bi, Gia Lâm, Hà Nội

Phương pháp nghiên cứu:

Thiết kế nghiên cứu: mô tả cắt ngang.

Cõ̃ mẫu: theo công thức tính cõ mẫu ${ }^{4}$ :

$$
\mathrm{n}=\mathrm{Z}^{2}(1-\mathrm{a} / 2) \frac{p(1-p)}{\Delta^{\mathrm{z}}}
$$

p: tỉ lệ học sinh viêm lợi, chọn $p=0,518$ theo nghiên cứu của Vũ Thị Sao Chi $2015^{5}, Z_{(1-a / 2)}=$ $1,96, \Delta=0,09$. Tính được $n=119$, cộng thêm $10 \%$ ta được $n=131$ học sinh. Thực tế chúng tôi khám được 129 học sinh.

Kỹ thuật chọn mẫu: chọn mẫu ngẫu nhiên, lập danh sách tất cả học sinh lớp 6 trường THCS Cổ Bi, sau đó chọn ngẫu nhiên 131 học sinh bằng phân mềm simple random.

Phương pháp thu thập thông tin: khám chỉ số GI, OHI-S, PI của học sinh:

- Khám và đánh giá chỉ số GI: khám 6 răng đại diện: $16,12,24,36,32,44$. Mỗi răng khám 4 mặt: ngoài, trong, gân,xa.

Xếp loại GI: rất tốt $(0)$, tốt $(0,1-0,9)$, trung bình $(1,0-1,9)$, kém $(2,0-3,0)$.

- Khám và đánh giá chỉ số OHI-S: khám chỉ số DI-S và CI-S cho 6 mặt răng đại diện: mặt ngoài răng 16,11,26,31 và mặt trong răng 36,46. $\mathrm{OHI}-\mathrm{S}=\mathrm{DI}-\mathrm{S}+\mathrm{CI}-\mathrm{S}$

Xếp loại DI-S, CI-S: rất tốt $(0)$, tốt $(0,1-0,6)$, trung bình $(0,7-1,8)$, kém $(1,9-3,0)$.

Xếp loại OHI-S: rất tốt $(0)$, tốt $(0,1-1,2)$, trung bình $(1,3-3,0)$, kém $(3,1-6,0)$.

- Khám và đánh giá chỉ số PI: khám các răng đại diện: 16,12,24,36,32,44. Mỗi răng khám 4 mặt: ngoài, trong, gân,xa.

Xếp loại PI: rất tốt $(0)$, tốt $(0,1-0,9)$, trung bình $(1,0-1,9)$, kém $(2,0-3,0)$.

Xưlý số liệu: bằng phân mềm SPSS 20.0

\section{KẾT QUẢ NGHIÊN CỨU}

Trong 129 học sinh tham gia nghiên cứu có 71 nam $(55,04 \%)$ và 58 nữ (44,96\%).

Bảng 1: Tỉ lệ viêm lợi của học sinh

\begin{tabular}{|c|c|c|c|c|}
\hline Viêm lợi & Nam n(\%) & Nữ n(\%) & Chung n(\%) & p \\
\hline Có & $56(78,87 \%)$ & $45(77,59 \%)$ & $101(78,29 \%)$ & \multirow{2}{*}{0,247} \\
\hline Không & $15(21,13 \%)$ & $13(22,41 \%)$ & $28(21,71 \%)$ & \\
\hline Tống & $71(100 \%)$ & $58(100 \%)$ & $129(100 \%)$ & \\
\hline
\end{tabular}

Nhânn xét: tỉ lệ viêm lợi ở nam là 78,87\%, nữ là $77,59 \%$, tỉ lệ chung là 78,29\%. Sự khác biệt về tî lệ viêm lợi giữa nam và nữ không có ý nghĩa thống kê với $\mathrm{p}=0,247$.

Bảng 2: Trung bình chỉ số GI của học sinh GI $\mathrm{X} \pm$ SD

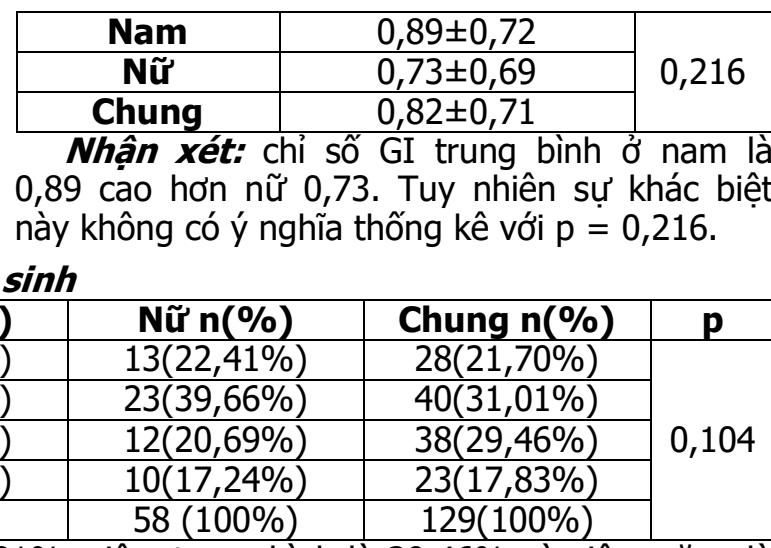

Bảng 3: Phân loai mức đô viêm lợ của hoc sinh

\begin{tabular}{|c|c|c|c|c|}
\hline Phân loại viêm Iợi & Nam n(\%) & Nữ n(\%) & Chung n(\%) & p \\
\hline Không viêm GI=0 & $15(21,13 \%)$ & $13(22,41 \%)$ & $28(21,70 \%)$ & \\
\hline Viêm nhẹ GI=0,1-1,0 & $17(23,94 \%)$ & $23(39,66 \%)$ & $40(31,01 \%)$ \\
\hline Viêm trung bình GI=1,1-2,0 & $26(36,62 \%)$ & $12(20,69 \%)$ & $38(29,46 \%)$ & 0,104 \\
\hline Viêm nặng GI=2,1-3,0 & $13(18,31 \%)$ & $10(17,24 \%)$ & $23(17,83 \%)$ \\
\hline Tổng & $71(100 \%)$ & $58(100 \%)$ & $129(100 \%)$ & \\
\hline
\end{tabular}

Nhân xét: tỉ lệ học sinh bị viêm lợi nhẹ là $31,01 \%$, viêm trung bình là $29,46 \%$ và viêm nặng là 17,83\%. Sự khác biệt về các mức độ viêm lợi giữa nam và nữ không có ý nghĩa thống kê với $p=0,104$.

Bảng 4. Trung binh chí số DI - S, CI $-S$, OHI -S của hoc sinh

\begin{tabular}{|c|c|c|c|c|}
\hline Chí số & Nam & Nũ & Chung & p \\
\hline DI-S & $1,07 \pm 0,52$ & $1,05 \pm 0,50$ & $1,06 \pm 0,51$ & 0,857 \\
\hline CI-S & $0,38 \pm 0,36$ & $0,37 \pm 0,36$ & $0,37 \pm 0,36$ & 0,910 \\
\hline OHI-S & $1,45 \pm 0,79$ & $1,42 \pm 0,76$ & $1,44 \pm 0,77$ & 0,864 \\
\hline
\end{tabular}

Nhận xét: trung bình chỉ số DI-S ở nam là 1,07 cao hơn nữ 1,05, sự khác biệt này không có ý 
nghĩa thống kê với $p=0,857$. Trung bình chỉ số CI-S ở nam là 0,38 cao hơn nữ 0,37 , sự khác biệt này không có ý nghĩa thống kê với $\mathrm{p}=0,910$. Trung bình chỉ số $\mathrm{OHI}-\mathrm{S}$ ở nam là 1,45 cao hơn nữ 1,42 , sự khác biệt này không có ý nghĩa thống kê với $\mathrm{p}=0,864$.

Bảng 5: Phân loại chí số DI-S của học sinh. Trong nghiên cứu của chúng tôi, tỉ lệ trẻ có chỉ số DI-S rất tốt là $0 \%$.

\begin{tabular}{|c|c|c|c|c|}
\hline Phân loại DI-S & Nam n(\%) & Nữ n(\%) & Chung n(\%) & P \\
\hline Tốt & $12(16,90 \%)$ & $5(8,62 \%)$ & $17(13,18 \%)$ & \\
\cline { 1 - 4 } Trung bình & $53(74,65 \%)$ & $50(86,21 \%)$ & $103(79,84 \%)$ & \multirow{2}{*}{0,621} \\
\hline Kém & $6(8,45 \%)$ & $3(5,17 \%)$ & $9(6,98 \%)$ & \\
\hline Tống & $71(100 \%)$ & $58(100 \%)$ & $129(100 \%)$ & \\
\hline
\end{tabular}

Nhận xét: tî lệ học sinh xếp loại cặn bám tốt là $13,18 \%$, trung bình là $79,84 \%$ và kém là $6,98 \%$. Sự khác biệt về các mức độ că̆n bám giữa nam và nữ không có ý nghĩa thống kê với $p=0,621$

Bảng 6: Phân loại chỉ sổ CI-S của học sinh. Trong nghiên cứu của chúng tôi, tỉ lệ trẻ có chỉ số CI-S kém là $0 \%$.

\begin{tabular}{|c|c|c|c|c|}
\hline Phân loại CI-S & Nam n(\%) & Nữ n(\%) & Chung n(\%) & p \\
\hline Rất tốt & $26(36,62 \%)$ & $21(36,21 \%)$ & $47(36,43 \%)$ & \\
\cline { 1 - 4 } Tốt & $20(28,17 \%)$ & $16(27,58 \%)$ & $36(27,91 \%)$ & \multirow{2}{*}{0,907} \\
\hline Trung bình & $25(35,21 \%)$ & $21(36,21 \%)$ & $46(35,66 \%)$ & \\
\hline Tống & $71(100 \%)$ & $58(100 \%)$ & $129(100 \%)$ & \\
\hline
\end{tabular}

Nhân xét: tỉ lê hoc sinh xếp loai cao răng rất tốt là $36,43 \%$, tốt là $27,91 \%$ và trung bình là $35,66 \%$. Sự khác biệt về các mức độ cao răng giữa nam và nữ không có ý nghĩa thống kê với $p=0,907$.

Bảng 7: Phân loại chỉ số OHI-S của học sinh. Trong nghiên cứu của chúng tôi, tỉ lệ trẻ có chì số OHI-S rất tốt là $0 \%$.

\begin{tabular}{|c|c|c|c|c|}
\hline Phân loại OHI-S & Nam n(\%) & Nũ̃ n(\%) & Chung n(\%) & P \\
\hline Tốt & $29(40,84 \%)$ & $24(41,38 \%)$ & $53(41,09 \%)$ & \multirow{2}{*}{0,737} \\
\cline { 1 - 4 } Trung bình & $41(57,75 \%)$ & $32(55,17 \%)$ & $73(56,59 \%)$ & \\
\hline Kém & $1(1,41 \%)$ & $2(3,45 \%)$ & $3(2,32 \%)$ & \\
\hline Tống & $71(100 \%)$ & $58(100 \%)$ & $129(100 \%)$ & \\
\hline
\end{tabular}

Nhận xét: tỉ lệ học sinh xếp loại OHI-S tốt là $41,09 \%$, trung bình là $56,59 \%$, kém là $2,32 \%$. Sự khác biệt về các mức độ xếp loại OHI-S giữa nam và nữ không có ý nghĩa thống kê với $p=0,737$.

Bảng 8: Phân loại chỉ số PI của học sinh. Trong nghiên cứu của chúng tôi, tỉ lệ trẻ có chỉ số PI-S rất tốt là $0 \%$.

\begin{tabular}{|c|c|c|c|c|}
\hline Phân loại PI & Nam n(\%) & Nữ n(\%) & Chung n(\%) & $\mathbf{P}$ \\
\hline Tốt & $6(8,45 \%)$ & $7(12,07 \%)$ & $13(10,08 \%)$ & \multirow{4}{*}{0,414} \\
\hline Trung bình & $42(59,15 \%)$ & $38(65,52 \%)$ & $80(62,01 \%)$ & \\
\hline Kém & $23(32,40 \%)$ & $13(22,41 \%)$ & $36(27,91 \%)$ & \\
\hline Tống & $71(100 \%)$ & $58(100 \%)$ & $129(100 \%)$ & \\
\hline
\end{tabular}

Nhân xét: tỉ lê học sinh xếp loai mảng bám tốt là $10,08 \%$, trung bình là $62,01 \%$ và kém là $27,91 \%$. Sự khác biệt về các mức độ mảng bám giữa nam và nữ không có ý nghĩa thống kê với $p=0,414$

Bảng 9: Trung binh chi số PI của hoc sinh

\begin{tabular}{|c|c|c|}
\hline PI & $X \pm$ SD & P \\
\cline { 1 - 2 } Nam & $1,99 \pm 0,64$ & \multirow{2}{*}{0,099} \\
\cline { 1 - 2 } Nữ & $1,82 \pm 0,49$ & \\
\cline { 1 - 2 } Chung & $1,91 \pm 0,58$ & \\
\cline { 1 - 2 } & &
\end{tabular}

Nhân xét: chỉ số PI trung bình ở nam là 1,99 cao hớn ở nữ 1,82 , tuy nhiên sự khác biệt này không có ý nghĩa thống kê với $p=0,099$.

\section{BÀN LUÂN}

Về thực trạng bệnh viêm lợi của học sinh: Cùng với sâu răng, viêm lợi là một trong hai bệnh răng miệng phổ biến nhất ở học sinh. Nghiên cứu của chúng tôi cho thấy tỉ lệ mắc viêm lợi của học sinh lớp 6 trường THCS Cổ Bi khá cao $78,29 \%$. Tỉ lệ viêm lợi trong nghiên cứu của chúng tôi thấp hơn so với kết quả điều tra sức khỏe răng miệng toàn quốc của Trần Văn Trường và cộng sự $2001^{3}$ (tỉ lệ viêm lợi ở trẻ em 12 tuổi là 92,6\%), tương đương với nghiên cứu của Nguyễn Anh Sơn 2019 tại Vinh Phúc ${ }^{6}$ (tỉ lệ học sinh bị viêm lợi là $81,1 \%$ ), cao hơn so với các tác giả khác như Quách Huy Chức 2013 tại Gia Lâm ${ }^{7}$ (tỉ lệ viêm lợi là 41,9\%), Vũ Thị Sao Chi 2015 tại Hải Dương ${ }^{5}$ (tỉ lệ viêm ợi là $51,8 \%$ ), Trương Mạnh Dũng 2011 tại Hà Nội ${ }^{8}$ (tỉ lệ viêm lợi chung là $64,74 \%)$. Sự khác nhau này là do nghiên cứu được thực hiện tại các thời điểm khác nhau và ở các vùng địa lý khác nhau. Tuy nhiên các kết quả đều cho thấy tỉ lệ viêm lợi ở học sinh vẫn còn cao. 
Mặc dù tỉ lệ viêm lợi trong nghiên cứu của chúng tôi khá cao nhưng chủ yếu là viêm lợi nhẹ $31,01 \%$ và viêm lợi trung bình $29,46 \%$, chỉ có $17,83 \%$ học sinh bị viêm lợi nặng. Kết quả viêm lợi nhẹ và trung bình chiếm tî lệ cao trong nghiên cứu của chúng tôi cũng tương tự với kết quả của các tác giả khác như: Bùi Thị Thu Hiền $2019^{9}$ nghiên cứu tại Bình Định (ở lứa tuổi 11-12 tỉ lệ viêm nhe và viềm trung bình đều chiếm gần $50 \%)$, Nguyễn Anh Sơn $2019^{6}$ nghiên cứu tại Vĩnh Phúc (trong số học sinh bị viêm lợi thì viêm lợi nhe chiếm $70,7 \%$, viêm lợi trung bình chiếm $26,1 \%)$. Các nghiên cứu trên tuy thực hiện tại các vùng địa lý khác nhau nhưng cho kết quả tương đồng nhau về mức độ viêm lợi. Điều này cho thấy để giảm tình trạng viêm lợi ở học sinh không quá phức tạp, chỉ cần tập trung vào giáo dục chăm sóc răng miệng cho học sinh là đủ.

Về tình trạng vệ sinh răng miệng của học sinh: Từ kết quả ở bảng 4 và bảng 5 cho thấy tình trạng cặn bám của học sinh ở mức trung bình. Trung bình điểm số cặn bám là 1,06, sự khác biệt chỉ số cặn bám ở nam 1,07 và nữ 1,05 không có ý nghĩa thống kê. Không có học sinh nào có xếp loại cặn bám rất tốt, số học sinh có xếp loại cặn bám tốt rất thấp $13,18 \%$, đa số là xếp loại trung bình 79,84\% và kém là 6,98\%. Điều này cho thấy việc thực hành VSRM của các em vẫn còn chưa đầy đủ và cần được củng cố thêm nữa. Nếu so sánh với kết quả của các tác giả khác như: Trần Thị Mỹ Hạnh $2012^{10}$ nghiên cứu tai Hà Nô̂i (điểm trung bình cặn bám ở nhóm 11 tuổi là 0,80), Bùi Quang Tuấn $2012^{11}$ nghiên cứu tại Ninh Thuận (điểm trung bình cặn bám ở nhóm 12 tuổi là 0,65 ) thì điểm số cặn bám trong nghiên cứu của chúng tôi cao hơn, điều này có thể là do học sinh trường THCS Cổ Bi chưa được tiếp cận với chương trình nha học đường nền kiến thức và thực hành CSRM của các em kém hơn. Kết quả ở bảng 4 và bảng 6 cho thây tình trạng cao răng của học sinh ở mức tốt: trung bình điểm số cao răng của học sinh là 0,37 , tỉ lệ học sinh có cao răng ở mức độ rất tốt (36,43\%) và tốt $(27,91 \%)$ khá cao, tỉ lể học sinh có xếp loại cao răng ở mức trung bình là $35,66 \%$ và không có học sinh nào xếp loại kém. Học sinh trong nghiên cứu của chúng tồi nằm trong độ tuổi 11-12, là lứa tuổi các răng vĩnh viễn mới mọc lên nên sự tích tụ cao răng chưa nhiều.

Điểm trung bình chỉ số OHI-S của học sinh là 1,44 . Sự khác biệt về điểm số OHI-S giữa nam và nữ không có ý nghĩa thống kê. Tỉ lệ học sinh có tình trạng VSRM trung bình là cao nhất $56,59 \%$, tiếp đến là tình trạng VSRM tốt
41,09\%, kém 2,32\%. Kết quả của chúng tôi cũng tương tự với kết quả nghiên cứu của Tạ Quốc Đại (2012) trên học sinh 12 tuổi tại Hà Nội (43,9\% học sinh có tình trạng vệ sinh răng miệng tốt), thấp hơn kết quả nghiên cứu của Lê Bá Nghĩa tại trường THCS Tân Mai, Hà Nội $(60,7 \%$ học sinh có tình trạng VSRM tốt). Tî lệ học sinh có tình trạng VSRM trung bình trong nghiên cứu của chúng tôi khá cao 56,59\%, điều này cho thấy kỹ năng thực hành CSRM của học sinh còn chưa tốt, cần có các chương trình can thiệp kịp thời, hiệu quả để cải thiện tình trạng VSRM của học sinh.

Kết quả ở bảng 8 và bảng 9 cho thây tình trạng mảng bám ở học sinh còn cao. Điểm trung bình mảng bám là 1,91 . Tỉ lệ học sinh có mức độ mảng bám tốt rất thấp $10,08 \%$, đa số ở mức trung bình $62,01 \%$ và kém 27,91\%. Mức độ mảng bám phản ảnh trực tiếp tình trạng VSRM, mức độ mảng bám cao là điều đáng báo động và cấp thiết phải có các biện pháp can thiệp làm giảm tình trạng mảng bám cho học sinh.

\section{KẾT LUÂN}

Tỉ lệ viêm lợi ở học sinh là $78,29 \%$, chủ yễu là viêm lợi nhẹ và trung bình.

Điểm trung bình chỉ số cặn bám là 1,06 . Số học sinh có xếp loại cặn bám rất tốt là $0 \%$, tốt là $13,18 \%$, trung bình $79,84 \%$, kém 6,98\%.

Điểm trung bình chỉ số cao răng là 0,37 . Số học sinh có xếp loại cao răng rất tốt là 36,43\%, tốt là $27,91 \%$, trung bình $35,66 \%$, kém $0 \%$.

Điểm trung bình chỉ số OHI-S là 1,44. Số học sinh có xếp loại OHI-S rất tốt là $0 \%$, tốt là $41,09 \%$, trung bình $56,59 \%$, kém 2,32\%.

Điểm trung bình chỉ số mảng bám là 1,91 . Số học sinh có xếp loại mảng bám bám rất tốt là $0 \%$, tốt là 10,08\%, trung bình 62,01\%, kém 27,91\%.

\section{KHUYẾN NGH!}

Cần đẩy mạnh công tác giáo dục nha khoa tại trường học, cung cấp cho học sinh kiến thức về chăm sóc sức khỏe răng miệng, hướng dẫn cho học sinh cách tự chăm sóc răng miệng.

Tuyên truyền cho học sinh và phụ huynh cách nhận biết sớm bệnh răng miệng và cần khám răng miệng định kỳ để dự phòng bệnh răng miệng hiệu quả.

Bên cạnh đó, cần khám răng miệng định kỳ cho học sinh, đánh giá tình trạng về sinh răng miệng, đánh giá hiệu quả của các chương trình chămm sóc răng miệng,...

TÀl LIỆU THAM KHẢO

1. Trịnh Đình Hải. Báo cáo tóm tắt kết quả điều tra chương trình chăm sóc sức khỏe răng miệng ở học 
sinh tiểu học tại Việt Nam 2011. Hội nghị Châu ÁThái Bình Dương lần thứ 6 về sức khỏe răng miệng cho học sinh các trường phổ thông năm 2011 tại Việt Nam:96.

2. Trương Mạnh Dũng, Ngô Văn Toàn. Nha cộng đồng tập 1. In: Nhà xuất bản Y học; 2013:160.

3. Trân Văn Trường và CS. Điều tra sức khỏe răng miệng toàn quốc, Nhà xuất bản Y học, Hà Nội; 2001.

4. Lưu Ngoc Hoạt. Phương pháp nghiên cứu sức khỏe cộng đồng. In: Nhà xuất bản Y hoc; 2013:188.

5. vũ̃ Thị Sao Chi, Nguyễn Thị Trang Nhung, Thẩm Chí Dũng. Thực trang sâu răng, viêm lợi và một số yếu tố liên quan ở học sinh trường Trung hợ cơ sở Tân Bình, thành phố Hải Dương năm 2015. Hội nghị khoa học-công nghê tuổi trẻ các trường đại học, cao đẳng Y-dược Việt Nam lần thứ
XVIII, 2016.

6. Nguyê̂n Anh Sơn. Thực trang và môt số yếu tố liên quan đến bệnh sâu răng, viêm lợi, hiệu quả can thiệp ở học sinh lớp 6 một số trường trung hoc cơ sở huyên Bình Xuyên, tỉnh Vĩnh Phúc. Luân án tiến sĩ y tể công cộng, viện vệ sinh dịch tễ Trung Ương,2019:52.

7. Quách Huy Chức. Thực trạng bệnh sâu răng, viêm lợi ở học sinh trường trung học cơ sở Bát Tràng, Gia Lâm, Hà Nôi năm 2012-2013. Luân văn thạc sĩ y học, Trường Đại học Y Hà Nội;2013:40.

8. Trương Manh Dũng. Thức trang viêm lợi ở hoc sinh lứa tuổi 11-14 tại trường Trung học cơ sở Hoàng Liệt-Quận Hoàng Mai-Hà Nội. Tạp chí y học dự phòng.2008;3(102)(2009):33-39.

\section{KHẢO SÁT NỒNG ĐÔ ASYMETRIC DIMETHYLARGININE HUYẾT TƯƠNG Ở BỆNH NHẦN BỆNH THẬN MẠN TÍNH GIAI ĐOẠN CUỐI}

\section{TÓM TẮT}

Mục tiêu: Khảo sát nồng độ ADMA huyết tương ở bênh nhân bênh thân man giai đoạn cuối (BTMGĐC) có chỉ định ghép thận và tìm hiểu mối liên quan với môt số yếu tố nguy cơ tim mach (YTNCTM). Đối tượng và phương pháp: Mô tả cắt ngang có đối chứng 118 bênh nhân có BTMGĐC có chỉ đinh ghép thận và 83 người khỏe mạnh tại Bệnh viện Quân y 103 từ tháng 3/2018-4/2020. Kết quả: Nồng đô ADMA trung bình nhóm bệnh: 0,61 $\mu \mathrm{mol} / \mathrm{l}$ cao hơn nhóm chứng: $0,32 \mu \mathrm{mol} / \mathrm{l}$ với $\mathrm{p}<0,001$. Có $75,4 \%$ bênh nhân tăng $A D M A$ huyết tương. Tăng nồng độ $A D M A$ liên quan với môt số YTNCTM như RLLP máu $(O R=$ $6,19)$, thừa cân béo phì $(O R=4,71)$, hút thuốc lá (OR $=3,58)$. Kết luâan: Tăng nồng độ ADMA huyết tương là phố biến và có mối liên quan với một số YTNCTM ở bênh nhân BTMTGĐC.

Tư khóa: Huyết tương asymetric dimethylarginin, Bệnh thận mạn giai đoạn cuối, Yếu tố nguy cơ tim mạch.

\section{SUMMARY \\ SURVEYING ON LEVEL OF PLASMA ASYMETRIC DIMETHYLARGININE IN END- STAGE RENAL DISEASE PATIENTS}

Objectives: Surveying on plasma asymmetric dimethylarginine in end-stage renal disease patients who were indicated kidney transplantation and association with cardiovascular risk factors. Subjects and Methods: A controlled cross-sectional study in 118 end-stage renal disease (ESRD) patients who have indication kidney transplantation and 83

${ }^{1}$ Bệnh viện Trung Uơng Quân đội 108

${ }^{2}$ Bệnh viện Quân y 103-Học viên Quân Y

Chịu trách nhiệm chính: Nguyển Thị Thúy

Email: thuys0401@gmail.com

Ngày nhân bài: 25.6.2021

Ngày phản biên khoa hoc: 23.8.2021

Ngày duyệt bài: 31.8.2021

\section{Nguyễn Thị Thúy ${ }^{1}$, Lê Việt Thắng²}

controlled healthy people at 103 Military hospital from March/2018 to April/2020. Results: The median concentration of plasma ADMA in the patient group: $0.61 \mu \mathrm{mol} / \mathrm{l}$ was higher than the control group: 0.32 $\mu \mathrm{mol} / \mathrm{l}$ with $\mathrm{p}<0.001$. There were $75.4 \%$ of patients increased plasma ADMA. There were correlation between ADMA level and dislipidemia $(O R=6.19)$, overweight or obesity $(\mathrm{OR}=4.71)$, smoke (OR = 3.58). Conclusion: Elevated plasma ADMA concentrations are common and associated with some cardiovascular risk factors in ESRD patients.

Keywords: Asymetric dimethylarginin (ADMA), End stage renal disease (ESRD), Kidney transplantation, cardiovascular risk factor.

\section{I. ĐĂT VẤN ĐỀ}

Bệnh thận mạn (BTM) ngày một gia tăng ở Việt Nam cũng như trên thế giới, là một trong nhưng bệnh mạn tính không lây gây tử vong đáng kể. Theo nghiên cứu đăng trên tạ chí Lancet, BTMT chiếm tỷ lê 9,1\% trong đó có tới 7,6\% bệnh nhân BTM tử vong do nguyên nhân tim mạch [1]. Khi BTMT tiến triển thì các yếu tố nguy cơ tim mạch (YTNCTM) đặc hiệu của thận cũng xuất hiện. Tân suất và mức độ xuất hiện các biến chứng tim mạch liên quan đến nhiều YTNC truyền thống như: tăng huyết áp, rối loạn mõ máu, béo phì, đái tháo đường, hút thuốc lá... Ngày nay, một số YTNCTM khác hay YTNCTM phi truyền thống như: protein niệu, homocystein, asymmetric dimethylarginine (ADMA)... cũng cho thấy những đóng góp trong việc xuất hiện các biến cố tim mach [2], [3]. ADMA có khả nằng ức chế sinh tổng hợp chất Nitric Oxide (NO), dẫn tới rối loạn chức năng nội mạc, co mạch, tăng huyết áp và xơ vữa động mạch [4]. Vì vậy, ADMA được 